\title{
Immobilized Aminoacylase on Porous Glass Beads
}

\author{
Yasuharu Yokote,* Masako Fujita, Gen Shimura, Sadao Noguchi, \\ Kazuo Kimura and Hirotoshi SAmEJima \\ Tokyo Research Laboratory, Kyowa Hakko Kogyo Co., Ltd., \\ Asahi-cho 3-6-6, Machida-shi, Tokyo \\ Received January 29, 1975
}

\begin{abstract}
The preparation and properties of immobilized aminoacylase on porous glass by covalent binding [Porous glass-CVB-aminoacylase] and the continuous enzymatic reactions using such preparations are described.

Two types of porous glass-CVB-aminoacylase were prepared. One was aminoacylase covalently bound to alkylaminosilane derivative of porous glass with glutaraldehyde as a coupling agent [Alkylamino-porous glass-CVB-aminoacylase], and the other was aminoacylase covalently bound to arylaminosilane derivative of porous glass with nitrous acid as a coupling agent [Arylamino-porous glass-CVB-aminoacylase]. The enzyme activities of such immobilized aminoacylases were 3.2 13.0 units/ml glass for the former and $1.9 \sim 6.8$ units $/ \mathrm{ml}$ glass for the latter. Especially, alkylamino porous glass-CVB-aminoacylase showed excellent stability at $\mathrm{pH} 6 \sim 9$ and temperature below $50^{\circ} \mathrm{C}$, and was able to be stored for more than six months without appreciable loss of the activity.

The continuous enzyme reaction using the alkylamino porous glass-CVB-aminoacylase packed in a column was operated for 54 days at $37^{\circ} \mathrm{C}$, and the half-life of the immobilized enzyme was calculated to be 78 days. From these results, it was recognized that such an immobilized aminoacylase on porous glass would be applicable in an industrial preparation of various L-amino acids from their DL-forms.
\end{abstract}

The utilization of enzymes as industrial catalysts has been limited because costs of enzymes are sometimes too expensive. However, recent development of immobilization techniques for enzymes has made the repeated use of enzymes possible, and this has widen the applicability of enzyme reactions in various industrial processes. ${ }^{1 \prime}$ Therefore a number of immobilized enzymes are now being evaluated from the standpoint of their applicabilities in food, pharmaceutical and chemical industries. It was reported by Smiley and Strandberg ${ }^{2}$ that some immobilized enzymes such as aminoacylase by Chibata et $a .^{3 \prime}$ and penicillinamidase by Self et al. ${ }^{4}$ were already operated in commercial scale.

Aminoacylases from various origins have been studied in relation to the optical resolution of DL-amino acids. ${ }^{5 \sim 7)}$ Therefore, a

* Present address: Food Development Dept. Food Division, Kyowa Hakko Kogyo Co., Ltd., Ohtemachi, Chiyoda-ku, Tokyo. number of immobilization methods for aminoacylase have also been raised..$^{3,8 \sim 10)}$

In order to apply an immobilized enzyme in an industrial process, selection of suitable carrier is practically important, and such carrier must have enough mechanical durability, appropriate pore size, relatively big surface area and reasonable price. Because of the advantages in the physical properties, the porous glass beads raised by Weetall ${ }^{11}$ seemed to be one of the promising carriers for immobilized enzymes.

Therefore, the authors prepared two types of immobilized aminoacylase covalently bound to the porous glass beads [Porous glass-CVBaminoacylase] according to the method of Weetall et al., ${ }^{11,12}$ and studied on the properties of such immobilized aminoacylases. Long-run operations of the immobilized enzymes were also studied. Those results are reported in the present paper. 


\section{MATERIALS AND METHODS}

1. Enzyme preparation. A commercial grade aminoacylase of Aspergillus sp. was purchased from the Amano Seiyaku Co., Ltd. (Japan). It contained $56 \%$ of protein, and its specific activity was $0.55 \mathrm{u} / \mathrm{mg}$ protein.

This crude enzyme was further purified by the following method: One hundred grams of the commercial grade aminoacylase was dissolved in 1 liter of $0.05 \mathrm{M}$ phosphate buffer ( $\mathrm{pH} 7.8$ ) containing $1 \mathrm{~mm} \mathrm{CoCl}_{2}$. The enzyme solution was treated by ammonium sulfate fractionation. Precipitates from the solution by 45 to $75 \%$ saturation with ammonium sulfate showed a specific activity of $1.0 \mathrm{u} / \mathrm{mg}$ protein.

The precipitate was again dissolved in $160 \mathrm{ml}$ of $0.02 \mathrm{M}$ phosphate buffer $(\mathrm{pH} 7.8)$ containing $1 \mathrm{mM}$ $\mathrm{CoCl}_{2}$. This solution was passed through a column (dia. $4.0 \mathrm{~cm}$ ) containing $400 \mathrm{ml}$ of Sephadex G-25, and $110 \mathrm{ml}$ of the active fraction was collected. The active fraction was then passed through a column (dia. $6.5 \mathrm{~cm}$ ) containing $700 \mathrm{ml}$ of DEAE-cellulose. The enzyme adsorbed on DEAE-cellulose was eluted with a linearly increasing gradient of sodium chloride from 0 to $1.0 \mathrm{M}$ in the same buffer described above. The active fraction from the DEAE-cellulose column was treated by ammonium sulfate precipitation, and the enzyme precipitated was further purified by gel-filtration using a Sephadex G-100 column. The purified aminoacylase thus obtained showed a specific activity of $4.5 \mathrm{u} / \mathrm{mg}$ protein.

2. Porous glass used. Alkylamino and arylamino derivatives of $96 \%$ silica-porous glass beads coated with $\mathrm{ZrO}_{2}{ }^{113}$ having average pore diameter of $550 \AA$ and particle size from 40 to 80 mesh (trade name: "Encor") were donated by the Corning Glass Works, Corning, N. Y., U.S.A.

3. Immobilization of aminoacylase to porous glass. The aminoacylase was bound to the arylamino derivative of porous glass by azo-linkage, and also to the alkylamino derivative of porous glass by glutaraldehyde according to the method by Weetall et al. ${ }^{11,12\}}$ Details of the coupling procedures are described as follows:

a) Preparation of arylamino-porous glass-CVBaminoacylase. Ten $\mathrm{ml}$ of $2 \mathrm{~N} \mathrm{HCl}$ and $0.25 \mathrm{~g}$ of solid $\mathrm{NaNO}_{2}$ were added to $1 \mathrm{~g}$ of arylamino derivative of porous glass beads. The diazotization reaction was carried out at $0^{\circ} \mathrm{C}$ for $20 \mathrm{~min}$ in a desiccator attached to an aspirator for removing air and gas bubbles from the glass beads. The diazotized glass beads were filtered off on a Buchner's funnel and washed with ice cold water containing $1 \%$ of sulfonic acid. Four $\mathrm{ml}$ of the enzyme solution were then added to the washed glass beads and the $\mathrm{pH}$ value of the mixture was adjusted at 8.5 with $0.5 \mathrm{M} \mathrm{NaHCO}$. The mixture was gently agitated on an ice-bath for $60 \mathrm{~min}$. Then, the glass beads were filtered off and washed with $0.1 \mathrm{M}$ phosphate buffer (pH 8) containing $5 \mathrm{M} \mathrm{NaCl}$ until no free protein could be detected in the washings.

b) Preparation of alkylamino-porous glass-CVBaminoacylase. Five $\mathrm{ml}$ of $2.5 \%$ glutaraldehyde solution were added to $1 \mathrm{~g}$ of alkylamino derivative of porous glass beads. The reaction was carried out at room temperature for $60 \mathrm{~min}$ in a desiccator described above. The glass beads were filtered off on a Buchner's funnel, and washed with water. Four $\mathrm{ml}$ of the enzyme solution ( $\mathrm{pH} 7.0$ ) were then added to the washed glass beads. The immobilization reaction was carried out at $0^{\circ} \mathrm{C}$ for $2 \mathrm{hr}$ on an ice bath with gentle agitation. The immobilized enzyme thus obtained was filtered off on a Buchner's funnel and washed well with $0.1 \mathrm{~m}$ phosphate buffer (pH 8.0) containing $5 \mathrm{M} \mathrm{NaCl}$ as described before.

\section{Methods for analysis}

a) Protein. Protein contents were determined by a colorimetric method of Lowry et al.., ${ }^{13}$ and calculated from a standard curve prepared with using bovine serum albumin.

b) Activity of native aminoacylase. A reaction mixture comprising $0.4 \mathrm{ml}$ of $0.1 \mathrm{M}$ veronal buffer (pH 8.5), $0.2 \mathrm{ml}$ of $0.5 \mathrm{mM} \mathrm{CoCl}, 0.2 \mathrm{ml}$ of $0.1 \mathrm{M}$ $\mathrm{N}$-acetyl-DL-methionine (pH 8.0), and $0.2 \mathrm{ml}$ of the enzyme solution, was incubated at $37^{\circ} \mathrm{C}$ for $30 \mathrm{~min}$. Then, the reaction was immediately stopped by heating the mixture for $3 \mathrm{~min}$ at $100^{\circ} \mathrm{C}$. The liberated Lmethionine was measured by a ninhydrin colorimetric method. ${ }^{14}$ ) One unit of the enzyme activity was defined as that amount required to liberate $1 \mu$ mole of $\mathrm{L}$ methionine per min.

c) Activity of immobilized aminoacylase. Determination of the enzyme activity of the immobilized aminoacylase was conducted by a column operation. Three $\mathrm{ml}$ of immobilized aminoacylase were packed into a glass column $(10 \times 80 \mathrm{~mm}, \mathrm{D} / \mathrm{H})$ with an outer jacket in which temperature controlled water was circulated for maintaining the temperature of the column at $37^{\circ} \mathrm{C}$. Unless otherwise noted, a substrate solution containing $0.1 \mathrm{M} \quad \mathrm{N}$-acetyl-DL-methionine (pH 8.0) and $1 \mathrm{~mm} \mathrm{CoCl} 2$ was charged into the column at a flow rate of $30 \mathrm{ml} / \mathrm{hr}(\mathrm{S} . \mathrm{V},=10)$. After several hours of continuous operation, the concentration level of the liberated $\mathrm{L}$-methionine in the effluent became constant. Then, the concentration of liberated Lmethionine in the effluent was determined by ninhydrin colormetrie method. ${ }^{14}$ )

The activity of the immobilized aminoacylase was expressed in term of micromoles of the liberated Lmethionine per minute by $1 \mathrm{ml}$ of the immobilized enzyme. (One gram of the immobilized enzyme corresponds to $2 \mathrm{ml}$ of packed volume of it.) 


\section{RESULTS}

1. Preparation of immobilized aminoacylase on porous glass beads and factors affecting to it

Arylamino-porous glass-CVB-aminoacylase and alkylamino-porous glass-CVB-aminoacylase were prepared by using enzyme solutions with different levels and purities. The results are summarized in Table I. In these experiments, native aminoacylases with three different purities, i.e., $0.55,1.0$ and $4.5 \mathrm{u} / \mathrm{mg}$ protein, were reacted with porous glass derivatives at three different concentrations of enzyme protein, i.e., 25,50 and $100 \mathrm{mg} / \mathrm{ml}$ glass.

As shown in Table I, alkylamino-porous glass-CVB-aminoacylase always shows higher enzyme activity than arylamino-porous glassCVB-aminoacylase under the same preparative condition. Also, it can be seen that the activity of immobilized aminoacylase depends on the purity of native enzyme used but does not depend on concentration of enzyme protein used under the experimental conditions employed.
When more enzyme was used, more was bound but less retention of enzyme activity was observed. A higher purity and less amount of native enzyme give better activity expressed by the immobilized enzyme.

A small amount of aminoacylase was adsorbed by the porous glass even in the absence of a coupling agent, and could not removed by washing with $5 \mathrm{M} \mathrm{NaCl}$. However, such adsorbed enzyme was readily eliminated when $0.1 \mathrm{M} \mathrm{N}$-acetyl-DL-methionine solution was passed through the enzyme column (See, Fig. 1). In the case of alkylamino-porous glass-CVBaminoacylase, the activity was stabilized within several hours.

Stabilities of two types of immobilized aminoacylase were compared with using continuous column operations. The results are shown in Fig. 1. The initial declines of activity within the first several hours are explained as leakage of adsorbed enzyme by the substrate solution. Even the immobilized enzymes used in this experiment originally showed low activity, the alkylamino-porous glass-CVB-amino

Table I. Preparation of Immobilized Aminoacylase on Porous Glass Beads

\begin{tabular}{|c|c|c|c|c|c|c|c|c|c|}
\hline \multirow[b]{2}{*}{$\begin{array}{l}\text { Carriers used } \\
\text { (Coupling } \\
\text { agent used }\end{array}$} & \multicolumn{3}{|c|}{ Aminoacylase added } & \multicolumn{3}{|c|}{ Aminoacylase bound } & \multicolumn{3}{|c|}{ Aminoacylase expressed } \\
\hline & $\begin{array}{c}\text { Specific } \\
\text { activity } \\
\text { (u/mg } \\
\text { protein) }\end{array}$ & $\begin{array}{l}\text { Protein } \\
\underset{\text { glass) }}{(\mathrm{mg} / \mathrm{ml}}(\mathrm{l}\end{array}$ & $\begin{array}{c}\text { Total ac- } \\
\text { tivity(A) } \\
(\mathrm{u} / \mathrm{ml} \\
\text { glass })\end{array}$ & $\begin{array}{l}\text { Protein }^{a)} \\
\text { (mg/ml } \\
\text { glass) }\end{array}$ & $\begin{array}{l}\text { Activity }{ }^{b)} \\
\text { bound(B) } \\
\text { (u/ml } \\
\text { glass) }\end{array}$ & $\begin{array}{l}\text { Ratio of } \\
\text { activity } \\
\text { bound } \\
(\mathrm{B} / \mathrm{A}, \%)\end{array}$ & $\begin{array}{l}\left.\text { Activity }{ }^{c}\right) \\
\text { assayed(C) } \\
(\mathrm{u} / \mathrm{ml} \\
\quad \text { glass })\end{array}$ & $\begin{array}{l}\text { Ratio of } \\
\text { activity } \\
\text { expressed } \\
(\mathrm{C} / \mathrm{B}, \%)\end{array}$ & $\begin{array}{l}\text { Recovery } \\
\text { of amino- } \\
\text { acylase } \\
\text { expressed } \\
(\mathrm{C} / \mathrm{A}, \%)\end{array}$ \\
\hline \multirow{4}{*}{$\begin{array}{l}\text { Arylamino- } \\
\text { glass } \\
\text { (Diazonium } \\
\text { salt) }\end{array}$} & 0.55 & 50 & 27.5 & 22.3 & 12.27 & 44.6 & 2.0 & 16.2 & 7.23 \\
\hline & 0.55 & 100 & 55.0 & 37.0 & 20.35 & 37.0 & 1.9 & 9.3 & 2.54 \\
\hline & 4.5 & 50 & 225.0 & 19.4 & 87.30 & 38.8 & 7.2 & 8.2 & 3.18 \\
\hline & 4.5 & 100 & 450.0 & 28.7 & 129.15 & 28.7 & 6.8 & 5.3 & 1.52 \\
\hline \multirow{7}{*}{$\begin{array}{l}\text { Alkylamino- } \\
\text { glass } \\
\text { (Glutar- } \\
\text { aldehyde) }\end{array}$} & 0.55 & 50 & 27.5 & 14.0 & 7.70 & 28.0 & 3.4 & 44.2 & 12.41 \\
\hline & 0.55 & 100 & 55.0 & 32.7 & 17.99 & 32.7 & 3.2 & 17.8 & 5.82 \\
\hline & 1.0 & 50 & 50.0 & 16.8 & 16.80 & 33.6 & 5.7 & 34.0 & 11.42 \\
\hline & 1.0 & 100 & 100.0 & 28.3 & 28.30 & 28.3 & 5.5 & 19.5 & 5.52 \\
\hline & 4.5 & 25 & 112.5 & 7.6 & 34.20 & 30.4 & 12.8 & 37.4 & 19.11 \\
\hline & 4.5 & 50 & 225.0 & 14.0 & 63.00 & 28.0 & 12.0 & 19.0 & 4.56 \\
\hline & 4.5 & 100 & 450.0 & 30.7 & 138.15 & 30.7 & 13.0 & 9.4 & 1.22 \\
\hline $\begin{array}{l}\text { Alkylamino glass } \\
\text { (no coupling } \\
\text { agent) }\end{array}$ & 1.0 & 50 & 50.0 & 3.9 & 3.90 & 7.8 & 1.47 & 32.0 & 2.94 \\
\hline $\begin{array}{l}\text { a) Calculat } \\
\text { b) Calculat } \\
\text { c) Activity } \\
\\
\left.\mathrm{CoCl}_{2}\right) \mathrm{t}\end{array}$ & ted from th & $\begin{array}{l}\text { he amount } \\
\text { he amount } \\
\text { yed by pas }\end{array}$ & $\begin{array}{l}\text { of prote } \\
\text { of prote } \\
\text { assing } 0.1\end{array}$ & $\begin{array}{l}\text { bound and } \\
\text { or } 0.2 \mathrm{M} \mathrm{l} \\
\text { ow rate, } \mathrm{S} \text {. }\end{array}$ & $\begin{array}{l}\text { and washing } \\
\text { d specific act } \\
\text { N-acetyl-DL } \\
. V .10 \text {. }\end{array}$ & $\begin{array}{l}\text { g water. } \\
\text { ctivity. } \\
\text { L-methio }\end{array}$ & le $(\mathrm{pH}$ & cont & $\mathrm{g} 1 \mathrm{mM}$ \\
\hline
\end{tabular}




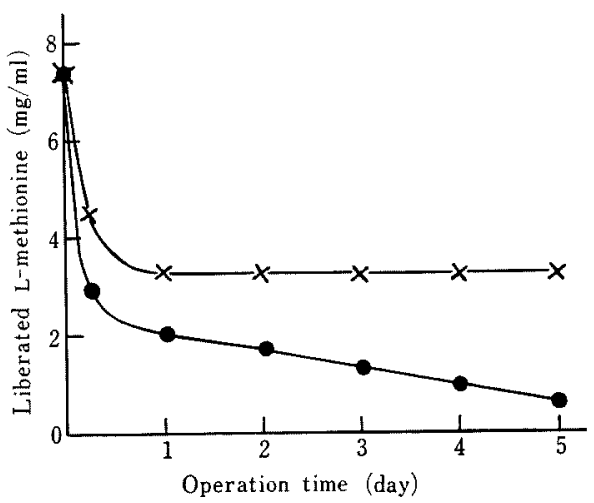

Fig. 1. Stability Profiles for Aminoacylase Immobilized on Alkylamino-porous Glass ( $x$ ), and Arylaminoporous Glass (•), in Continuous Column Operation.

Temperature was maintained at $37^{\circ} \mathrm{C}$ and flow-rate was kept at $10 \mathrm{ml} / \mathrm{hr} / \mathrm{ml}$ glass. Substrate solution comprised $0.1 \mathrm{M}$ acetyl-DL-methionine (pH 8.0) and $10 \mathrm{~mm} \mathrm{CoCl}_{2}$. The immobilized enzymes were prepared from crude enzyme (specific activity 0.55 ) of Table I.

acylase was apparently more stable than the arylamino-porous glass-CVB-aminoacylase.

From the data described above, it became evident that the alkylamino-porous glass-CVBaminoacylase was superior to the arylaminoporous glass-CVB-aminoacylase.

Therefore, in the subsequent experiments, only alkylamino-porous glass-CVB-aminoacylase was employed.

\section{Properties of alkylamino-porous glass-CVB- aminoacylase}

a) Optimum $\mathrm{pH}$. The $\mathrm{pH}$-activity relationship of the immobilized enzyme and the native enzyme was examined in the $\mathrm{pH}$ region from 6.5 to 9.0. The results are shown in Fig. 2. The immobilized enzyme had $\mathrm{pH}$ optimum at 8.0 and showed rather constant activity in the $\mathrm{pH}$ region from 6.5 to 9.0 .

b) Optimum temperature. The effect of temperature on the immobilized enzyme activity was examined in the column operation in which temperature was varied by circulating temperature controlled water in the outerjacket. As shown in Fig. 3, the optimum temperature for activity was found to be around $55^{\circ} \mathrm{C}$.

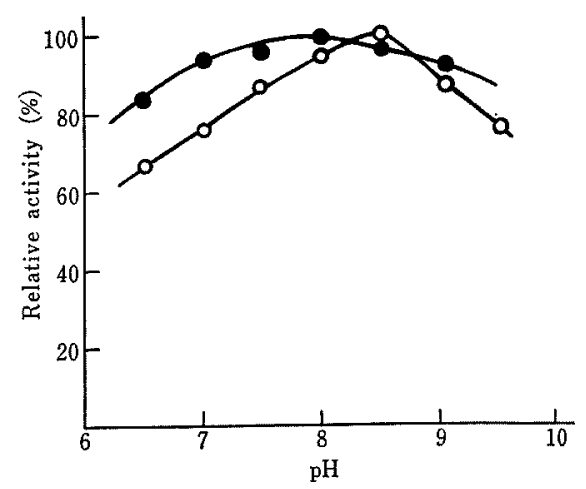

FIG. 2. Effect of $\mathrm{pH}$ on the Activity of Immobilized Aminoacylase (•), and Free Aminoacylase $(O)$.

Immobilized aminoacylase on alkylamino-porous glass was used in a column. Substrate solution comprised $0.1 \mathrm{M}$ acetyl-DL-methionine and $10 \mathrm{mM} \mathrm{CoCl}$. The native soluble enzyme was incubated in the same substrate solution for $30 \mathrm{~min}$ at $37^{\circ} \mathrm{C}$, The $\mathrm{pH}$ of substrate was varied from 6.5 to 9.0 with $\mathrm{NH}_{4} \mathrm{OH}$.

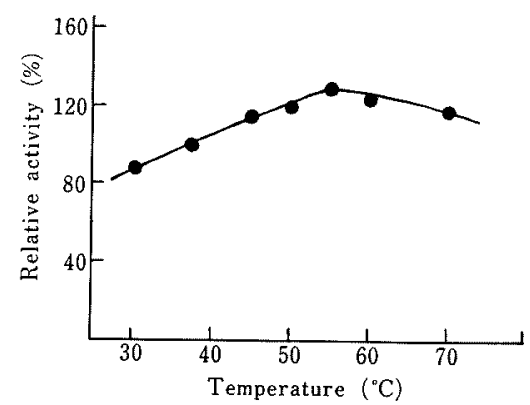

FIG. 3. Effect of Temperature on Continuous Operation of Immobilized Aminoacylase Columns.

The columns of aminoacylase coupled to alkylaminoporous glass were charged with $0.2 \mathrm{M}$ acetyl-DLmethionine $(\mathrm{pH} 8.0)$ containing $10 \mathrm{mM} \mathrm{CoCl}_{2}$ at various temperature.

c) Heat stability. The heat stability of the immobilized aminoacylase was also determined in the presence of the substrate. Both immobilized and native enzymes were exposed to different temperatures for $16 \mathrm{hr}$, and then the residual activities were assayed at $37^{\circ} \mathrm{C}$. The results are shown in Fig. 4.

It is evident that the immobilized enzyme is more stable against higher temperature than the native enzyme. From the results shown in Figs. 3 and 4, the favorable temperature for long term operation of the immobilized enzyme must be less than $45^{\circ} \mathrm{C}$. 


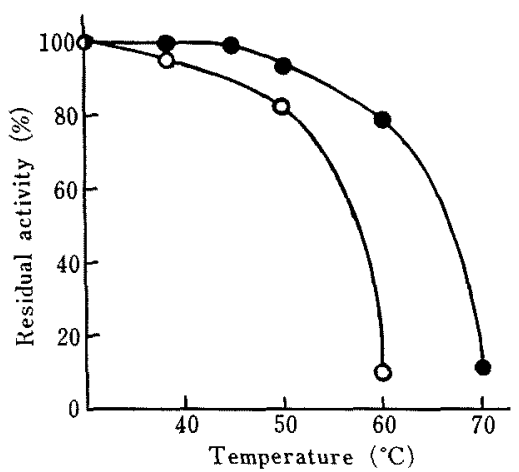

Fig. 4. Effect of Temperature on Stability of Immobilized Aminoacylase.

Aminoacylase coupled to alkylamino-porous glass $(\bullet)$, and native soluble enzyme (O), were incubated for $16 \mathrm{hr}$ in $0.1 \mathrm{M}$ acetyl-DL-methionine ( $\mathrm{pH} \mathrm{8.0)}$ containing $0.5 \mathrm{~mm} \mathrm{CoCl}$. The temperature was varied from 5 to $70^{\circ} \mathrm{C}$. The residual enzyme activity of the immobilized enzyme in a column was assayed at $37^{\circ} \mathrm{C}$.

Stability of the immobilized enzyme stored at $5^{\circ} \mathrm{C}$ was also examined. Then, it was found that the enzyme activity was completely kept intact even after six months storage.

d) Effect of buffers and salts on the enzyme activity. N-Acetyl-DL-methionine was dissolved in deionized water and various buffer and salt solutions at a concentration of $0.2 \mathrm{M}$. All these solutions contained $1 \mathrm{mM} \mathrm{CoCl}_{2}$ and

Table II. Effect of Buffer and Salt Solutions oN ACTIVITy of IMMOBILIZED AMINOACYLASE

The activity was assayed in column operation on a flow rate of S.V. 10.

\begin{tabular}{|c|c|}
\hline pH 8.0 buffer or salt solution & Activity $(\%)^{a)}$ \\
\hline deionized water & 100 \\
\hline $0.02 \mathrm{M} \mathrm{Na}_{2} \mathrm{HPO}_{4}-\mathrm{NaH}_{2} \mathrm{PO}_{4}$ & 87 \\
\hline $0.02 \mathrm{M} \mathrm{H}_{3} \mathrm{BO}_{4}-\mathrm{Na}_{2} \mathrm{CO}_{3}$ & 87 \\
\hline $0.02 \mathrm{M} \mathrm{NaHCO}_{3}$ & 87 \\
\hline $0.02 \mathrm{M} \mathrm{Na}_{2} \mathrm{~B}_{4} \mathrm{O}_{7}$ & 68 \\
\hline $0.02 \mathrm{M} \mathrm{H}_{3} \mathrm{BO}_{4}-\mathrm{Na}_{2} \mathrm{~B}_{4} \mathrm{O}_{7}$ & 82 \\
\hline $0.02 \mathrm{M} \mathrm{K}_{2} \mathrm{HPO}_{4}-\mathrm{KH}_{2} \mathrm{PO}_{4}$ & 82 \\
\hline $0.1 \mathrm{M} \quad \mathrm{K}_{2} \mathrm{HPO}_{4}-\mathrm{KH}_{2} \mathrm{PO}_{4}$ & 64 \\
\hline $0.1 \mathrm{M} \mathrm{NaCl}$ & 86 \\
\hline $0.5 \mathrm{M} \mathrm{NaCl}$ & 73 \\
\hline $0.1 \mathrm{M} \quad \mathrm{CH}_{3} \mathrm{COONa}$ & 79 \\
\hline $0.5 \mathrm{M} \quad \mathrm{CH}_{3} \mathrm{COONa}$ & 42 \\
\hline
\end{tabular}

a) Activity: Relative concentration of L-methionine liberated in effluent from each column. were adjusted to $\mathrm{pH} 8.0$ with sodium hydroxide. These substrate solutions were charged in the immobilized enzyme columns, and the relative concentrations of L-methionine liberated.in effluents from these columns are shown in Table II.

As the result, the substrate solution using deionized water gave the best activity, and all the buffer and salt solutions showed less activity.

e) Substrate specificity. The relative activity of the immobilized aminoacylase on alkylamino porous glass toward several $\mathrm{N}$ acetyl-DL-amino acids were determined using column operation, and the results are shown in Table III.

Among the various substrates tested, Nacetyl-DL-methionine was hydrolyzed most rapidly. The specificity pattern of the immobilized enzyme was similar to that of the native enzyme.

\section{Table III. Substrate-Specificity of IMMOBILIZED AMINOACYLASE}

A substrate solution of $0.1 \mathrm{M} \mathrm{N}$-acetyl-DL-aminoacids ( $\mathrm{pH} 8.0$ ) was charged on immobilized enzyme columns at a flow rate of S.V. 10 under standard conditions. The liberated amino acids were determined by the ninhydrin colorimetric method. The activity toward $\mathrm{N}$-acetyl-DL-methionine was taken as the control.

\begin{tabular}{lc} 
Substrate & $\begin{array}{c}\text { Relative } \\
\text { activity }(\%)\end{array}$ \\
\hline N-Acetyl-DL-methionine & 100 \\
N-Acetyl-DL-valine & 53 \\
N-Acetyl-DL-tryptophan & 65 \\
N-Acetyl-DL-phenylalanine & 98 \\
N-Acetyl-DL-alanine & 35 \\
N-Acetyl-DL-phenylglycine & 10 \\
\hline
\end{tabular}

f) Effect of concentration and flow rate of substrate solution in column operation. The effect of substrate ( $\mathrm{N}$-acetyl-DL-methionine) concentration on the activity of the immobilized aminoacylase was examined with using column operation. Substrate concentrations were varied from 0.02 to $0.6 \mathrm{M}$, and the flow rates of the substrate solution were varied up to S.V. 40 . The results are shown in Fig. 5. 


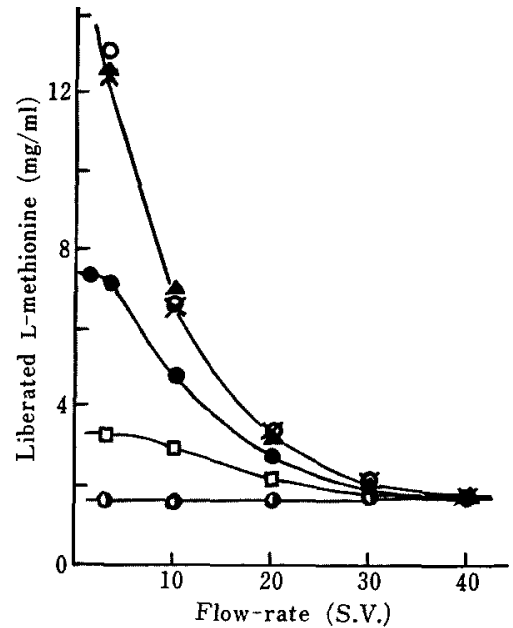

FIG. 5. Effect of Substrate Concentration and Flowrate on the Activity of Immobilized Aminoacylase.

Two $\mathrm{ml}$ of aminoacylase coupled to alkylamino-porous glass was packed in a column and charged with acetylDL-methionine solution (pH 8.0) containing $0.5 \mathrm{mM}$ $\mathrm{CoCl}_{2}$ at flow-rate between S.V. 1 and S.V. 40. The concentration of substrate was varied from $0.02 \mathrm{M}$ to $0.6 \mathrm{M}$. When continuous reaction at $37^{\circ} \mathrm{C}$ was stabilized, L-methionine liberated in effluent was measured.

А $0.6 \mathrm{M} ; 0,0.4 \mathrm{M} ; \times, 0.2 \mathrm{M} ; \bullet, 0.1 \mathrm{M} ; \square, 0.05 \mathrm{M}$; $0,0.02 \mathrm{M}$.

At the lowest concentration of substrate, i.e., $0.02 \mathrm{M}$ of $\mathrm{N}$-acetyl-DL-methionine, the reaction rate was constant in all the region of flow rate from S.V. 1 to 40 . On the other hand, at substrate concentrations higher than $0.2 \mathrm{M}$, no distinct difference of reaction rate was observed at each flow rate used.

In order to observe the leakage of enzyme from the immobilized enzyme used in the column operation, the effluent obtained in the case of $0.6 \mathrm{M}$ substrate solution was incubated for $24 \mathrm{hr}$ at $37^{\circ} \mathrm{C}$. No increase of L-methionine was observed, and this showed no leakage of enzyme during the course of continuous operation.

\section{Continuous column operation of immobilized aminoacylase}

For the purpose of examining the applicability of the immobilized aminoacylase on alkylamino porous glass for the industrial resolution of DL-amino acids, the long term operation of the immobilized enzyme in a column was carried out.

A substrate solution ( $\mathrm{pH} \mathrm{8.0)} \mathrm{comprising}$ $0.1 \mathrm{M} \mathrm{N}$-acetyl-DL-methionine and $1 \mathrm{mM} \mathrm{CoCl}$ was passed through a column containing $3 \mathrm{ml}$ of alkylamino-porous glass-CVB-aminoacylase $(6.85 \mathrm{u} / \mathrm{ml}$ glass $)$ at flow rates of S.V. 5 and 10 . The temperature in the columns was maintained at $37^{\circ} \mathrm{C}$. The change of activity during 54 days operation are shown in Fig. 6.

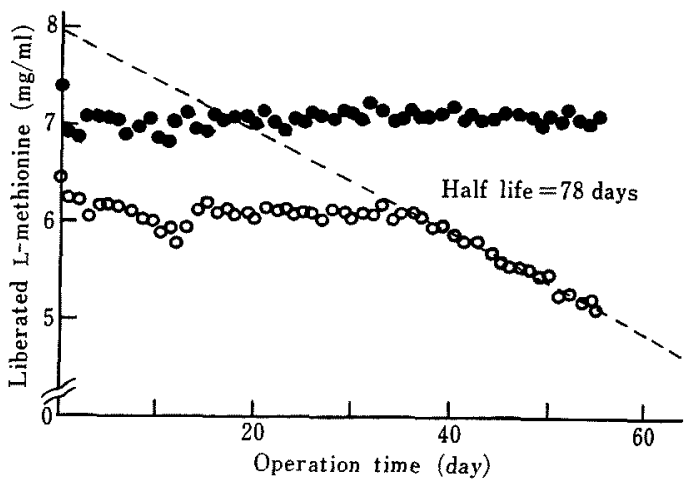

FIG. 6. Continuous Operation of Aminoacylase Covalently Bound to Alkylamino-porous Glass.

Columns containing $3 \mathrm{ml}$ of immobilized enzyme were continuously operated at $37^{\circ} \mathrm{C}$ using a substrate solution ( $\mathrm{pH} \mathrm{8.0)}$ comprised $0.1 \mathrm{M}$ acetyl-DL-methionine and $1 \mathrm{~mm} \mathrm{CoCl}$. The flow-rates were S.V.5 (e) and S.V. $10(\mathrm{O})$

At flow rate of S.V. 5, the concentration of L-methionine liberated in the effluent was maintained around $7.1 \mathrm{mg} / \mathrm{ml}$ during the whole experimental period, and this meant $48 \%$ hydrolysis of the racemic substrate or $96 \%$ hydrolysis of the L-form used. A slow decline was observed at a flow rate of S.V. 10 after the continuous operation of 40 days, and the half-life of the immobilized enzyme could be calculated to be 78 days from the declining curve of S.V. 10 in Fig. 6 . When a substrate solution containing $0.2 \mathrm{M} \mathrm{N}$-acetyl-DL-methionine was charged into the column, complete hydrolysis of the L-form substrate was attained at a flow-rate of S.V. 2.

L-Methionine was isolated by concentration of the effluent and crystallized by the addition of ethanol. The yield of L-methionine was $94 \%$ of the theoretical value, and $[\alpha]_{D}^{25}$ of it was 
$+23.4^{\circ}(c=1.0$, in $6 \mathrm{~N} \mathrm{HCl})$. On the other hand, $\mathrm{N}$-acetyl-D-methionine was recovered from the crystallization mother liquor and racemized by heating in acidic condition. The racemized substrate could be hydrolyzed again by the immobilized enzyme without any trouble.

\section{DISCUSSION}

Immobilized enzyme technology has been developed remarkably in recent years, but a few immobilized enzymes has been applied in industrial processes. This fact may be accounted for poor durability of the immobilized enzymes hitherto prepared and extremely high cost of the support materials employed.

Aminoacylase is a well known enzyme which has already been immobilized on DEAEcellulose and DEAE-Sephadex and applied for the practical resolution of DL-amino acids. ${ }^{3)}$ However, it is assumed that support materials such as cellulose and dextran derivatives are not ideal for large-scale column operation. In this study, the authors were interested in not only aminoacylase as a practical enzyme but also the physico-chemical properties of porous glass. Porous glass has physical strength in a column operation and stability against microbial attacks. Also, its big surface area and desirable pore size resulted in the effective retention of enzyme activity. ${ }^{12}$,

The commercial aminoacylase used in this study contained some amounts of cellulase activity. Therefore, cellulose and dextran derivatives used in the purification of the enzyme were often decomposed by the crude aminoacylase. Dialysis of the enzyme using cellophane membrane also could not be employed by the same reason. From these reason, cellulose and dextran derivatives did not seem to be suitable support material for immobilized aminoacylase. However, in the case of covalent binding of the enzyme of the porous glass, the contaminant cellulase did not show any inhibitory effect for the preparation of immobilized enzyme.

From the results shown in Table I, it can be suggested that the more potent immobilized enzyme will be prepared if the more purified enzyme with higher specific activity will be employed for the preparation. These data also suggest that the use of less amount of enzyme per unit volume of porous glass may give better retention of enzyme activity and higher yield of enzyme activity expressed.

In the long term continuous operation of the alkylamino-porous glass-CVB-aminoacylase, the half-life of the immobilized enzyme was calculated to be 78 days when a substrate solution, i.e., $0.1 \mathrm{~m} \mathrm{~N}$-acetyl-DL-methionine, was passed through the column at a flow rate of S.V. 10, but no declining of activity was observed at a lower flow rate, i.e., S.V. 50. The stability of the immobilized aminoacylase looks much better than that of the immobilized aminoacylase hitherto reported.

Calculating from the data of Fig. 6, if $0.1 \mathrm{M}$ $\mathrm{N}$-acetyl-DL-methionine is passed through the column at a flow rate of S.V. 5 at $37^{\circ} \mathrm{C}$, about $25 \mathrm{~kg}$ of L-methionine can be produced by continuous operation of 1 liter of the immobilized enzyme for one month. This production capacity may be improved by preparing more potent immobilized aminoacylase.

\section{REFERENCES}

1) R. D. Falb, Biotech. Bioeng. Symp., No. 3, 177 (1959).

2) K. L. Smiley and G. W. Strandberg, "Advances in Applied Microbiology," Vol. 15, ed. by D. Perlman, Academic Press Inc., New York, N. Y., 1972, p. 13.

3) I. Chibata, T. Tosa, T. Sato, T. Mori and Y. Matsuo, Proc. 4th International Fermentation Symp., "Ferment. Technol. Today," 1972, p. 383.

4) D. A. Self, G. Kay, M. D. Lilly and P. Dunnill, Biotech. Bioeng., 11, 337 (1969).

5) K. R. Rao, S. M. Birnbaum, R. B. Kingsley and J. P. Greenstein, J. Biol. Chem., 198, 507 (1952).

6) K. Michi and H. Nonaka, Nippon Nôgeikagaku Kaishi, 28, 343 (1954).

7) Y. Yokote, H. Kushiro, S. Kudo and Y. Noguchi, ibid., 43, 50 (1969).

8) M. A. Mitz and L. J. Summaria, Nature, 189, 576 (1961).

9) Kyowa Hakko Kogyo Kabushikikaisha, France Patent, 1471792 (1966). 
10) T. Tosa, T. Mori, N. Fuse and I. Chibata, Enzymologia, 31, 214 (1966).

11) H. H. Weetall, Science, 166, 615 (1969).

12) H. H. Weetall and N. B. Havewala, Biotech. Bio- eng. Symp. No. 3, 241 (2972).

13) O. H. Lowry, N. J. Rosebrough, A. L. Forr and R. T. Randall, J. Biol. Chem., 193, 265 (1951).

14) S. Morre and W. H. Stein, ibid., 176367 (1948). 